\title{
Growth rate, protein:RNA ratio and stoichiometric homeostasis of submerged macrophytes under eutrophication stress
}

\author{
W. Xing ${ }^{1, \star, \star \star}$, Q. Shi ${ }^{1,2, * *}$, H. Liu ${ }^{1,3}$ and G. Liu ${ }^{1}$ \\ ${ }^{1}$ Key Laboratory of Aquatic Botany and Watershed Ecology, Wuhan Botanical Garden, Chinese Academy of Sciences, \\ Wuhan 430074, P.R. China \\ 2 Yiyang Municipal Environmental Protection Bureau, Yiyang 413000, P.R. China \\ 3 University of Chinese Academy of Sciences, Beijing 100049, P.R. China
}

Received January 26, 2016 - Revised March 23, 2016 - Accepted March 24, 2016

\begin{abstract}
Growth rate hypothesis (GRH) and stoichiometric homeostasis of photoautotrophs have always been questioned. However, little is known about GRH and stoichiometric homeostasis of aquatic plants, especially submerged macrophytes. Therefore, we aim to test the GRH and explore stoichiometric homeostasis of four freshwater submerged macrophytes under eutrophication stress. At the single species level and the multi-species level, N:P ratios of Potamogeton maackianus, Myriophyllum spicatum, Vallisneria natans and Ceratophyllum demersum had no consistent trends with growth rates. However, protein:RNA ratios of P. maackianus, M. spicatum and V. natans all correlated negatively with growth rates, demonstrating GRH can apply to freshwater submerged macrophytes, even though they are threatening by eutrophication stress. Protein:RNA ratios positively correlated with N:P ratios in culture media and tissues in submerged macrophytes except in P. maackianus (30d), suggesting effects of varying N:P ratios in culture media on protein:RNA ratios are basically in concert with tissue N:P ratios under short-time eutrophication stress. Stoichiometric homeostasis coefficients $\left(H_{\mathrm{N}: \mathrm{P}}\right)$ indicated submerged macrophytes have weak homeostasis. Stoichiometric homeostasis of $V$. natans was stronger than those of $P$. maackianus, $M$. spicatum and $C$. demersum. The differences in $\mathrm{GRH}$ and homeostasis of the four submerged macrophytes may be due to species traits.
\end{abstract}

Key-words: growth rate hypothesis / stoichiometric homeostasis / N:P ratio / protein:RNA ratio / submerged macrophytes / eutrophication stress

Résumé - Taux de croissance, rapport protéines : ARN, et homéostasie stœchiométrique de macrophytes submergés sous un stress d'eutrophisation. L'hypothèse du taux de croissance (GRH) et l'homéostasie stœchiométrique des photoautotrophes ont toujours été remises en question. Les plantes aquatiques, les macrophytes submergés en particulier, ont reçu moins d'attention parce qu'ils sont stressés par l'eutrophisation dans le monde entier. Ici, nous voulons tester la GRH et étudier l'homéostasie stœchiométrique de quatre macrophytes submergés d'eau douce sous le stress de l'eutrophisation. Au niveau d'une seule espèce et au niveau multi-spécifique, les rapports N:P de Potamogeton maackia, Myriophyllum spicatum, Vallisneria natans et Ceratophyllum demersum n'ont aucune relation avec les taux de croissance. Cependant, les rapports protéines:ARN de P. maackianus, M. spicatum et $V$. natans sont tous négativement corrélés avec les taux de croissance, ce qui démontre que la GRH peut s'appliquer aux macrophytes submergés d'eau douce, même s'ils sont menacés par le stress de l'eutrophisation. Les rapports protéines:ARN sont positivement corrélés aux rapports $\mathrm{N}: \mathrm{P}$ dans les milieux de culture et les tissus des macrophytes submergés, sauf dans P. maackianus (30d), suggérant que les effets de rapports N:P variables en milieu de culture sont essentiellement associés aux rapports N:P des tissus sous contrainte d'eutrophisation de courte durée. Les résultats de $H_{\mathrm{N}: \mathrm{P}}$ indiquent que les macrophytes immergés ont une faible homéostasie. L'homéostasie stœchiométrique de V. natans était plus forte que celle de P. maackianus, $M$. spicatum et $C$. demersum, indiquant que $V$. natans peut tolérer plus de stress d'eutrophisation et qu'elle est une espèce plus appropriée pour la restauration.

Mots-clés : hypothèse du taux de croissance / homéostasie stœchiométrique / rapport N:P / rapport protéine :ARN / macrophytes submergés / stress d'eutrophisation

\footnotetext{
* Corresponding author: xingwei108@wbgcas.cn

$\star \star$ The first two authors contributed equally to this work.
} 


\section{Introduction}

The growth rate hypothesis (GRH) predicts a positive correlation between growth rate and RNA content because growth depends upon the protein synthesis machinery (Giordano et al., 2015; Sterner and Elser, 2002). The GRH has been intensively tested and generally supported via both theoretical and empirical analysis in heterotrophs, such as zooplankton, arthropods and bacteria (Hessen et al., 2007; Makino et al., 2003; Vrede et al., 2002). Excess nutrients uptake and storage in photoautotrophs may obscure the relationship between $\mathrm{C}: \mathrm{N}: \mathrm{P}$ stoichiometry and growth rate (Ågren, 2004, 2008; Matzek and Vitousek, 2009), resulting in uncertainty of applicability of the GRH to photoautotrophs. Increasing GRH tests have shown that the GRH can apply to algae and vascular plants (Flynn et al., 2010; Giordano et al., 2015; Yu et al., 2012). However, the applicability of the GRH to aquatic plants is entirely unclear.

The successful tests of GRH in heterotrophs and photoautotrophs have demonstrated tight linkages among growth rate, RNA content, protein content and C:N:P stoichiometry (Giordano et al., 2015; Hessen et al., 2007; Matzek and Vitousek, 2009). Generally, the negative relationships between growth rate and $\mathrm{N}: \mathrm{P}$ ratio have been recognized as successful tests of GRH (Güsewell, 2004; Makino et al., 2003; Matzek and Vitousek, 2009; Yu et al., 2012). However, because of luxury uptake and storage in photoautotrophs, parts of body $\mathrm{N}$ and $\mathrm{P}$ were not used for growth. Thus, N:P ratio is not a good indicator of GRH tests of photoautotrophs. In comparison, protein:RNA ratio is directly applicable to the GRH as an indicator of the relative demand for P-rich 'assembly machinery' and the N-rich 'raw materials' collectively needed for protein synthesis (Karpinets et al., 2006; Klausmeier et al., 2004; Matzek and Vitousek, 2009). Previous studies in unicellular organisms and phytoplankton have shown that the protein:RNA ratios are lower when growth rates are higher (Berdalet et al., 1994; Karpinets et al., 2006), whereas Matzek and Vitousek (2009) found no link between growth rate and protein:RNA ratio in pines. However, protein:RNA data from higher aquatic plants are scarce. There is no other study that has characterized protein:RNA ratios in aquatic vascular plants varying in growth rate.

Stoichiometric homeostasis is the ability of an organism to keep its body chemical composition constant, despite varying inputs (Meunier et al., 2014; Sterner and Elser, 2002). Generally, autotrophic organisms are considered to be nonhomeostatic or weakly homeostatic, whereas heterotrophs are thought to be strictly homeostatic (Persson et al., 2010; Sterner and Elser, 2002). Previous studies have also documented that stoichiometric homeostasis of plants is lower than that of animals and bacteria, but higher than that of plankton and fungi (Makino et al., 2003; Sterner and Elser, 2002; Xing et al., 2015; Yu et al., 2011). Plant stoichiometry varies with growth rate and the surrounding environment (Ågren and Weih, 2012). Stoichiometric homeostatic regulation reflects underlying physiological and biochemical allocations as organisms respond to their surrounding environments (Hessen et al., 2004) and thus the degree of homeostasis may be highly relevant to fitness and to a species' ecological strategy on the one hand (Frost et al., 2005) and to recycling processes of superfluous material on the other one (Meunier et al., 2014).

Water eutrophication is a worldwide environmental problem. Almost all submerged macrophytes in eutrophic environments are being stressed by high nutrients ( $\mathrm{N}$ and $\mathrm{P}$ ) concentrations (Wang et al., 2012). To our knowledge, there are no studies about submerged macrophytes linking GRH to eutrophication stress. Therefore, in the study, we want to:

1. test whether the GRH was applicable to four freshwater submerged macrophytes under eutrophication stress;

2. explore stoichiometric homeostasis of four freshwater submerged macrophytes under eutrophication stress.

\section{Materials and methods}

\subsection{Experimental design}

Four submerged macrophytes, Potamogeton maackianus, Myriophyllum spicatum, Ceratophyllum demersum and Vallisneria natans were collected from Honghu lake $\left(29^{\circ} 38^{\prime}\right.$ $\left.29^{\circ} 59^{\prime} \mathrm{N}, 113^{\circ} 11^{\prime}-113^{\circ} 28^{\prime} \mathrm{E}\right)$. Honghu Lake, the seventh largest freshwater lake in China and the largest lake on the Jianghan Plain, is located in the southwest of Honghu City, Hubei province, China. The lake covers an area of $348 \mathrm{~km}^{2}$ $\left(760 \mathrm{~km}^{2}\right.$ on $\left.1950 \mathrm{~s}\right)$, with an average water depth of $1.34 \mathrm{~m}$. It is used for aquatic cultivation, water supply, and irrigation. Because of extensive water conservancy constructions, Honghu Lake was changed an overflowing lake to a semi-closed one during the 1950s-1970s. With rapid development of the local economy since 1980s, a large quantity of wastewater has been discharged directly into the lake. Honghu Lake has becoming eutrophic gradually, which consequently threatens diversity of aquatic organisms. At present, the water quality of Honghu Lake can be categorized into Type II according to Environmental Quality Standard for Surface Water in China (GB38382002) (Meng, 2009). Upon collection, the $30 \mathrm{~cm}$-long apicals of P. maackianus, $M$. spicatum and C. demersum and the whole plants of $V$. natans were cleaned thoroughly and pre-incubated in insolated tap water for 7 days under natural conditions in a greenhouse at Wuhan Botanical Garden, Chinese Academy of Sciences $\left(114^{\circ} 24^{\prime} \mathrm{E}, 30^{\circ} 33^{\prime} \mathrm{N}\right)$.

After pre-incubation, $15 \mathrm{~cm}$-long apicals of $P$. maackianus, $M$. spicatum and $C$. demersum and $20 \mathrm{~cm}$-long shoots of $V$. natans were prepared before planting, respectively. Polyvinyl chloride polymer (PVC) cylinders (inner diameter $25 \mathrm{~cm}$, height $50 \mathrm{~cm}$ ) were used and firstly filled with $10 \mathrm{~cm}$ sand rinsed with distilled water. For each species, 16 uniform plants were planted into each PVC cylinder. Then, cylinders were filled with insolated tape water, and nutrient concentrations were adjusted with chemical agents. According to field investigation and preliminary results, the $\mathrm{N}, \mathrm{P}$ concentrations and $\mathrm{N}: \mathrm{P}$ ratios were designed as Table 1 . The designed concentrations of $\mathrm{N}$ and $\mathrm{P}$ in culture media were obtained by different additions of $\mathrm{NH}_{4} \mathrm{NO}_{3}$ and $\mathrm{K}_{2} \mathrm{HPO}_{4}$.

Each treatment had six replications. Culture solutions were replaced every 3 days to keep media concentration and ratio stable. The experiment period was designed as 15 days 
Table 1. Nine treatments $\left(T_{1-9}\right)$ of $N, P$ concentrations and N:P ratios.

\begin{tabular}{cccccccccc}
\hline & $\mathrm{T}_{1}$ & $\mathrm{~T}_{2}$ & $\mathrm{~T}_{3}$ & $\mathrm{~T}_{4}$ & $\mathrm{~T}_{5}$ & $\mathrm{~T}_{6}$ & $\mathrm{~T}_{7}$ & $\mathrm{~T}_{8}$ & $\mathrm{~T}_{9}$ \\
\hline $\mathrm{N}$ (mg.L $\left.\mathrm{L}^{-1}\right)$ & 1.80 & 1.80 & 1.80 & 3.60 & 3.60 & 3.60 & 5.40 & 5.40 & 5.40 \\
$\mathrm{P}\left(\mathrm{mg} . \mathrm{L}^{-1}\right)$ & 0.36 & 0.24 & 0.12 & 0.36 & 0.24 & 0.12 & 0.36 & 0.24 & 0.12 \\
$\mathrm{~N}:$ P ratio & $5: 1$ & $7.5: 1$ & $15: 1$ & $10: 1$ & $15: 1$ & $30: 1$ & $15: 1$ & $22.5: 1$ & $45: 1$ \\
\hline
\end{tabular}

because growth was inhibited by eutrophication stress (Figure S.1). Three replications were harvested on $10 \mathrm{~d}$ and $15 \mathrm{~d}$, respectively. In addition, another six replications of $P$. maackianus were treated for 30 days to study the effect of relatively long-term eutrophication stress on growth rate.

\subsection{Tissue assays}

Leaves of submerged macrophytes at each shoot tip were collected at harvest time. Some were stored immediately in liquid nitrogen before determinations of RNA and protein. Others were oven-dried at $80^{\circ} \mathrm{C}$ for at least $48 \mathrm{~h}$, powdered and sieved with $0.1-\mathrm{mm}$ mesh for determinations of carbon, nitrogen and phosphorous.

For RNA measurements, the total RNA isolation and purification of $P$. maackianus were performed using Takara minibest universal RNA extraction kit (Code: 9767 Takara, Otsu, Japan); the total RNA isolation and purification of $M$. spicatum and $V$. natans were performed using Takara minibest universal RNA extraction kit and fruit-mate ${ }^{\mathrm{TM}}$ for RNA purification (Code: 9192 Takara, Otsu, Japan) The quality and quantity of the RNA extracts were assessed spectrophotometrically by a standard procedure. Contamination due to phenol/carbohydrates and proteins was determined by recording A260/A230 and A260/A280 absorbance ratios, respectively. In order to verify RNA integrity, extracts were fractioned by electrophoresis in a 1.2\% agarose gel, stained with ethidium bromide, and visualized under UV light.

Total protein content of the samples was determined according to Bradford (1976), using bovine serum albumin as the standard.

Total C concentrations were measured by TOC analyzer (Multi N/C 2100, Jena, Germany) (Xing et al., 2015). Total $\mathrm{N}$ concentrations were analyzed using the micro-Kjeldahl method (Bremner, 1996). Total P concentrations were measured by the ammonium molybdate method after persulfate oxidation (Kuo, 1996).

\subsection{Data analysis}

The growth rates were calculated as $\ln \left(M_{t} / M_{0}\right) / t$, where $M_{0}$ is the initial dry biomass, $M_{t}$ is the final dry biomass, and $t$ is the time interval. Pearson correlation analysis was used to assess the relationships between $\mathrm{C}: \mathrm{N}: \mathrm{P}$ ratios, protein:RNA ratios and growth rates. Regression analysis was performed to determine the relationships between protein:RNA ratios and N:P ratios in culture media and tissues. All analysis was performed by IBM SPSS Statistics V19 (Armonk, USA).
An organism's degree of stoichiometric homeostasis was characterized by the stoichiometric homeostasis coefficients $(H)$ :

$$
\log (y)=\log (c)+\log (x) / H
$$

where $x$ is the resource nutrient stoichiometry (e.g. N:P), $y$ is the organism's nutrient stoichiometry (same units as resource) and $c$ is a constant (Sterner and Elser, 2002). Oneway ANOVA followed by Duncan's multiple range test was performed to determine the significant difference among submerged macrophyte species. Significance was set at $p<0.05$.

\section{Results}

\subsection{Growth rate and C:N:P Stoichiometry}

At the single species level, for 15-day cultured $P$. maackianus, growth rate positively correlated with tissue $\mathrm{C}: \mathrm{N}$, tissue $\mathrm{C}: \mathrm{P}$ and tissue N:P (Figure 1). For 30-day cultured P. maackianus, growth rate positively correlated with tissue $\mathrm{C}: \mathrm{N}$, tissue $\mathrm{C}: \mathrm{P}$, while negatively with tissue N:P (Figure 2). For M. spicatum, growth rate positively correlated with tissue $\mathrm{C}: \mathrm{N}$, tissue C:P and tissue N:P (Figure 3). For V. natans, growth rate negatively correlated with tissue $\mathrm{C}: \mathrm{N}$, tissue $\mathrm{C}: \mathrm{P}$ and tissue $\mathrm{N}: \mathrm{P}$ (Figure 4). For $C$. demersum, growth rate correlated positively with tissue $\mathrm{C}: \mathrm{N}$, tissue $\mathrm{C}: \mathrm{P}$, and negatively with tissue $\mathrm{N}: \mathrm{P}$ (Figure 5). At the multi-species level, growth rate positively correlated with tissue $\mathrm{C}: \mathrm{N}$, tissue $\mathrm{C}: \mathrm{P}$ and tissue $\mathrm{N}: \mathrm{P}$ (Figure 6). In general, tissue $\mathrm{C}: \mathrm{N}$ and tissue $\mathrm{C}: \mathrm{P}$ in submerged macrophytes increased with the increase of growth rate beside in $V$. natans though most of correlations between them were not significant, and tissue N:P had no consistent trend for four submerged macrophytes.

\subsection{Growth rate and protein:RNA ratio}

At the single species level, for $P$. maackianus (15d and 30d), M. spicatum and V. natans, protein:RNA ratios all negatively correlated with growth rates (Figures 1-5). Because RNA content in $C$. demersum was below the detection limit, thus, we made correlation analysis between growth rate and protein content (Figure 5) and tissue $\mathrm{P}(r=-0.440, p=0.236)$ (data not shown). At the multi-species level, protein:RNA ratio also negatively correlated with growth rate (Figure 6).

\subsection{Protein:RNA ratio and N:P ratio}

Beside $P$. maackianus (30d), protein:RNA positively correlated with N:P in media and tissues of $P$. maackianus (15d), 
W. Xing et al.: Knowl. Manag. Aquat. Ecosyst. (2016) 417, 25
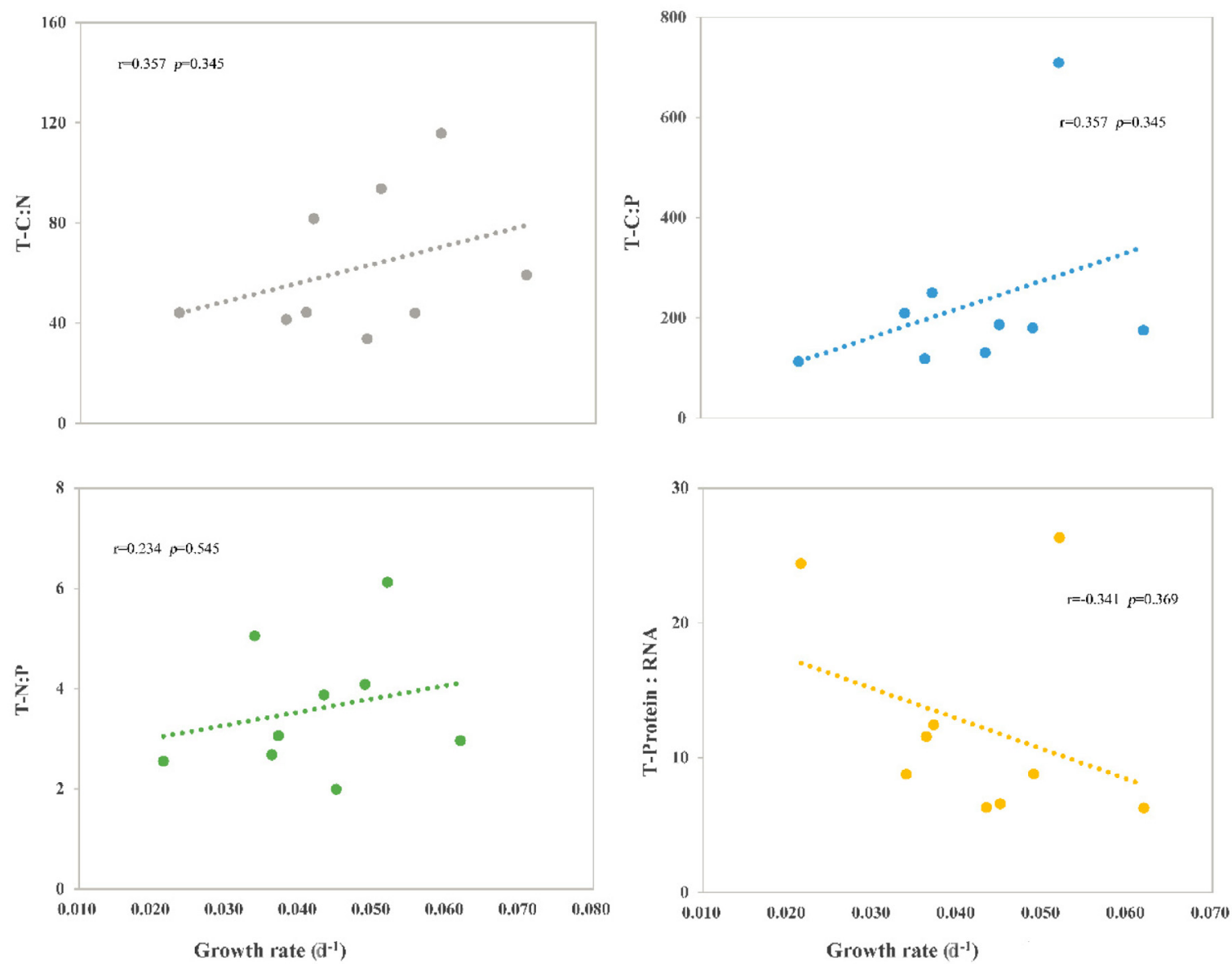

Fig. 1. Correlations between tissue C:N, C:P, N:P, protein:RNA and growth rate in 15d-cultured P. maackianus at single species level.
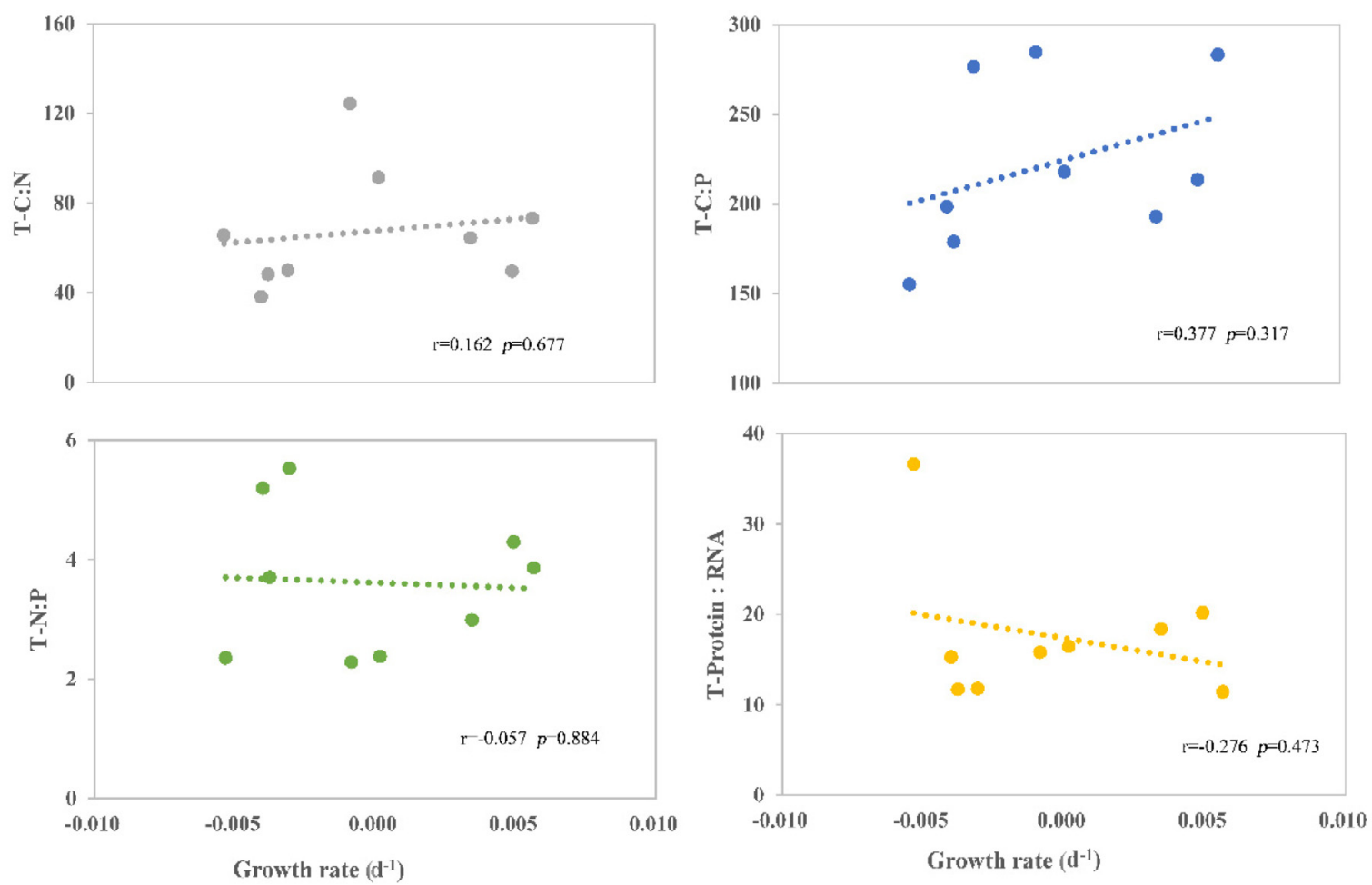

Fig. 2. Correlations between tissue C:N, C:P, N:P, protein:RNA and growth rate in 30d-cultured P. maackianus at single species level. 
W. Xing et al.: Knowl. Manag. Aquat. Ecosyst. (2016) 417, 25
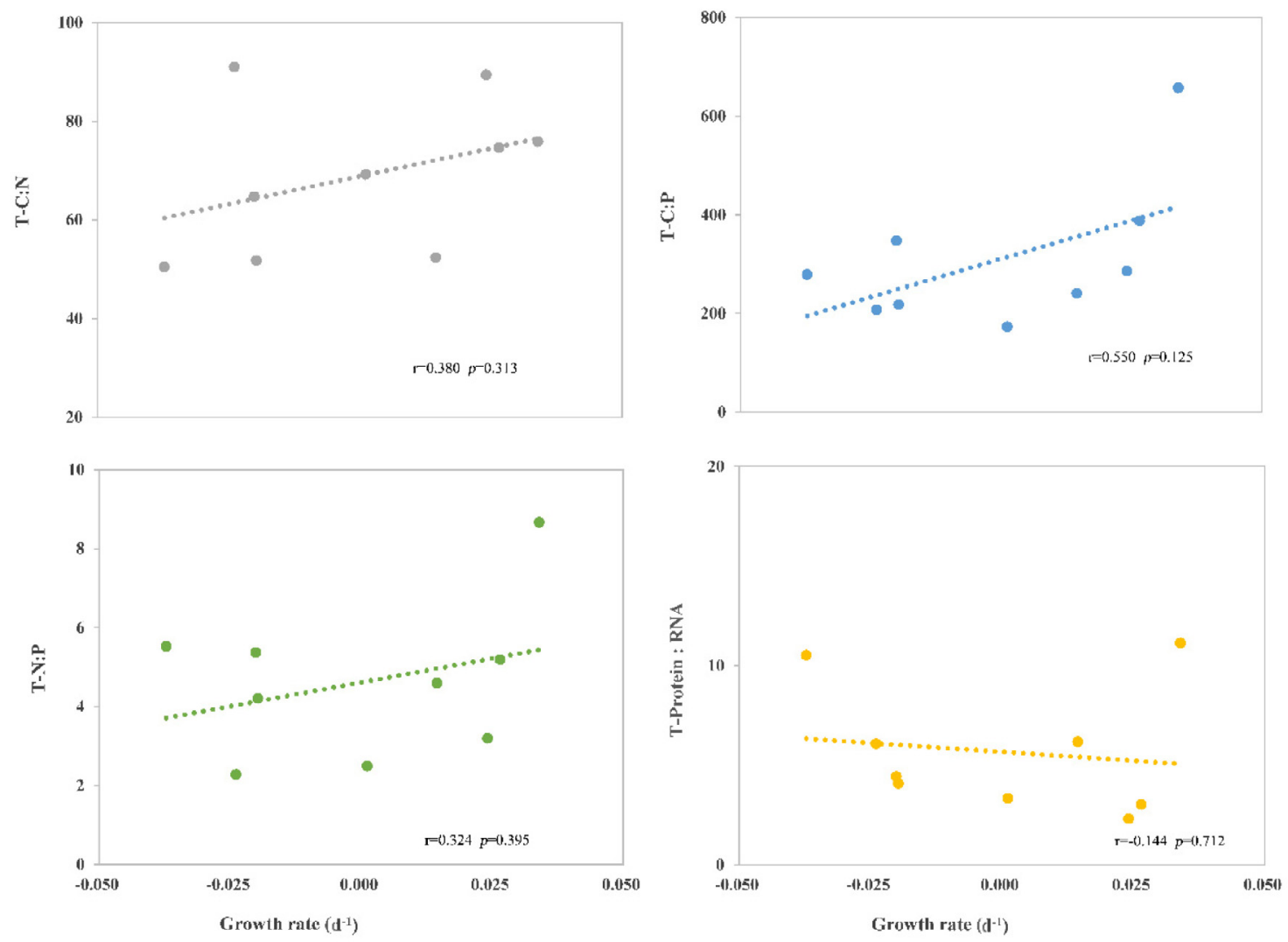

Fig. 3. Correlations between tissue C:N, C:P, N:P, protein:RNA and growth rate in M. spicatum at single species level.
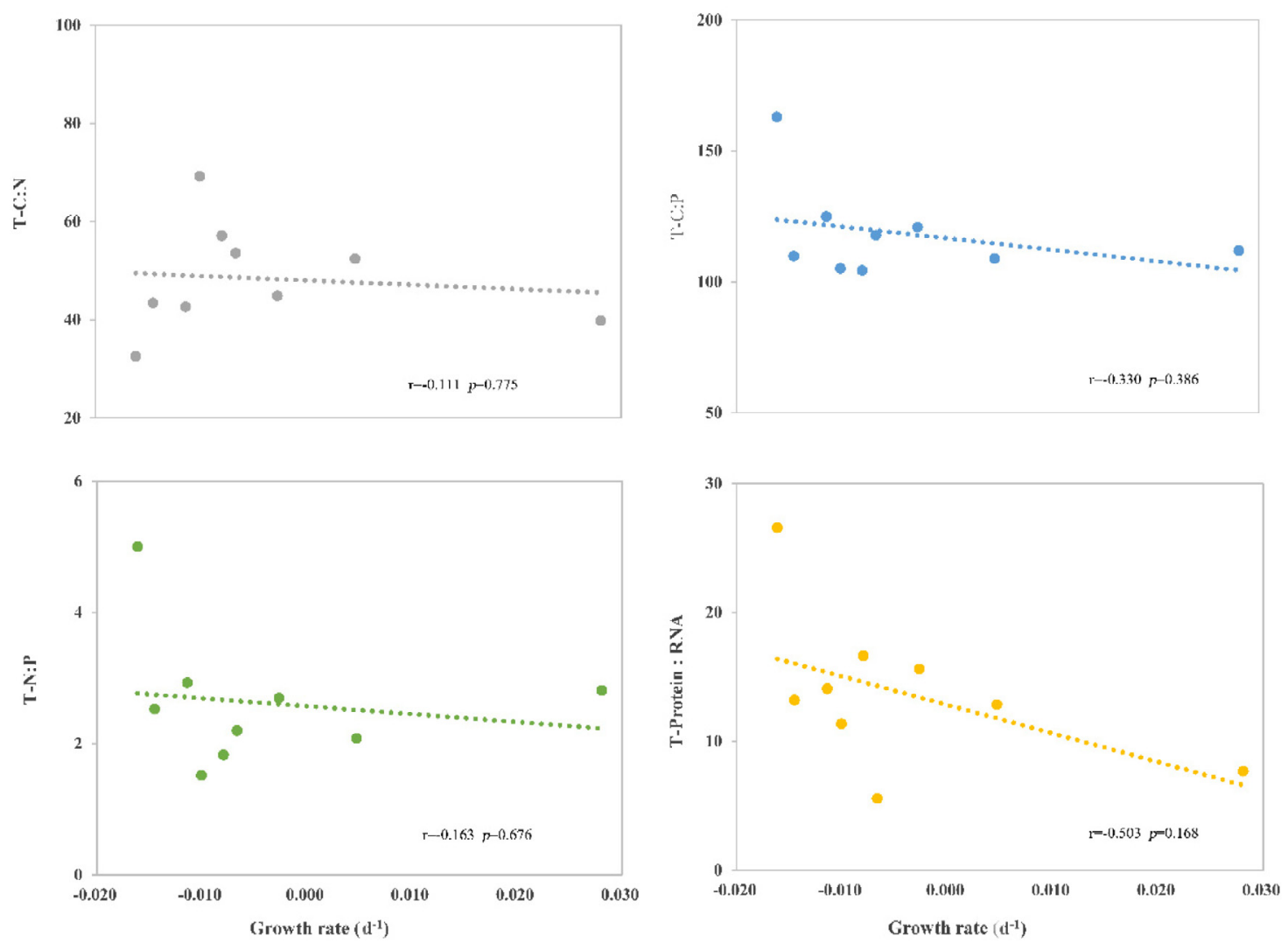

Fig. 4. Correlations between tissue C:N, C:P, N:P, protein:RNA and growth rate in V. natans at single species level. 
W. Xing et al.: Knowl. Manag. Aquat. Ecosyst. (2016) 417, 25
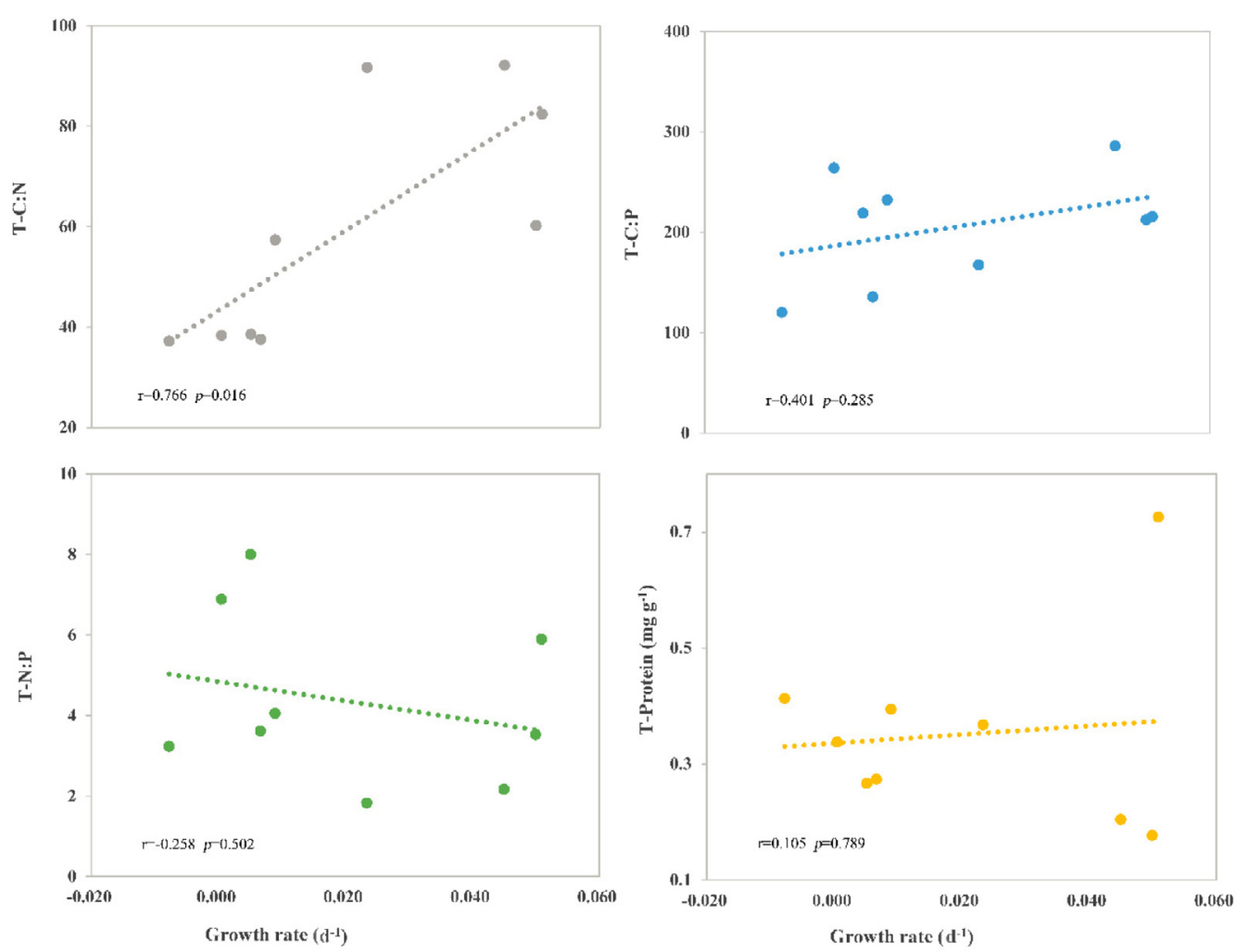

Fig. 5. Correlations between tissue C:N, C:P, N:P, protein content and growth rate in $C$. demersum at single species level. No protein:RNA provided because RNA content of $C$. demersum was below detection limit.
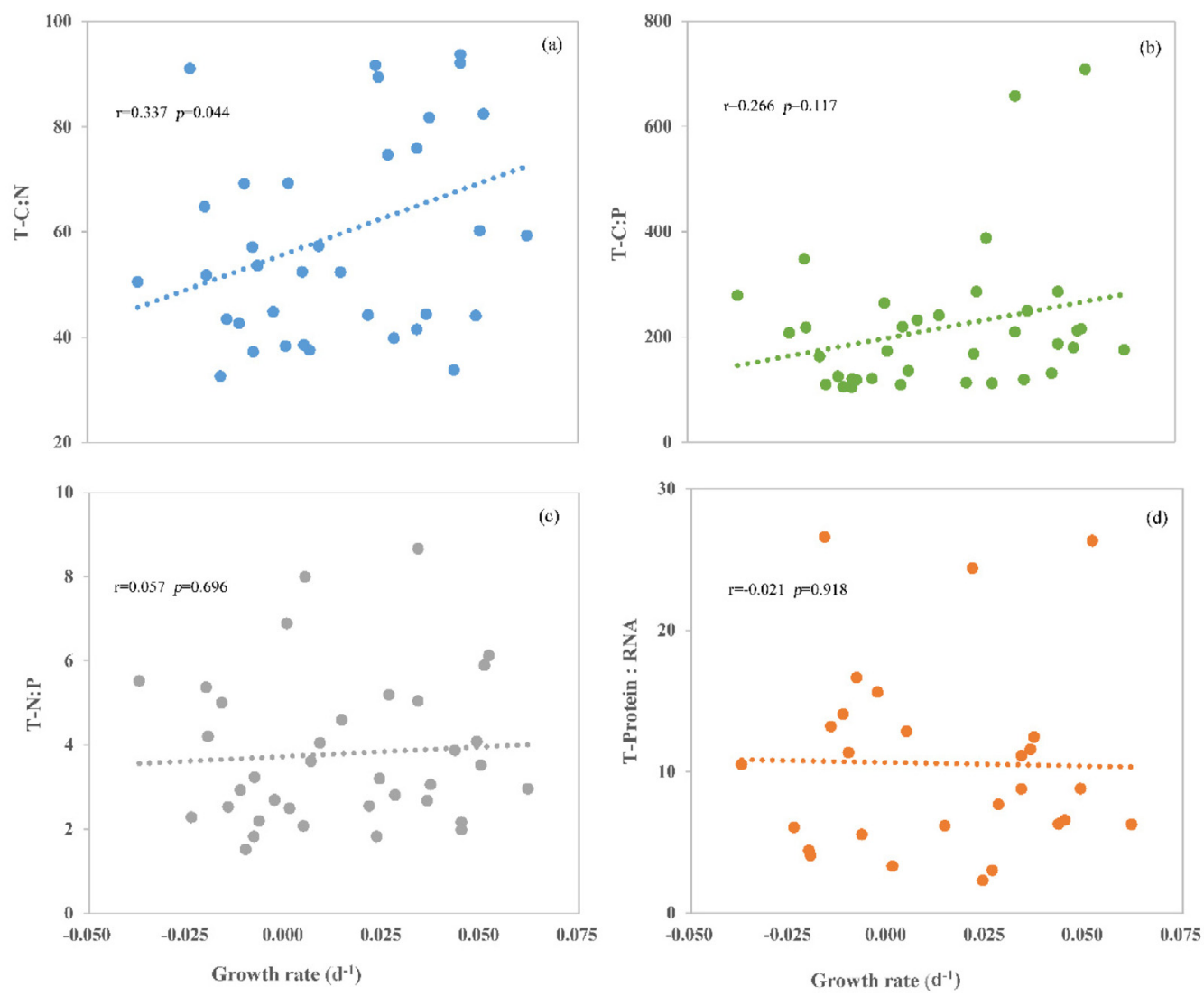

Fig. 6. Correlations between (a) tissue C:N ( $n=36,9$ treatments, 4 species), (b) C:P ( $n=36,9$ treatments, 4 species), (c) N:P ( $n=36,9$ treatments, 4 species), (d) protein:RNA ( $n=27,9$ treatments, 3 species) and growth rate at multi-species level. 


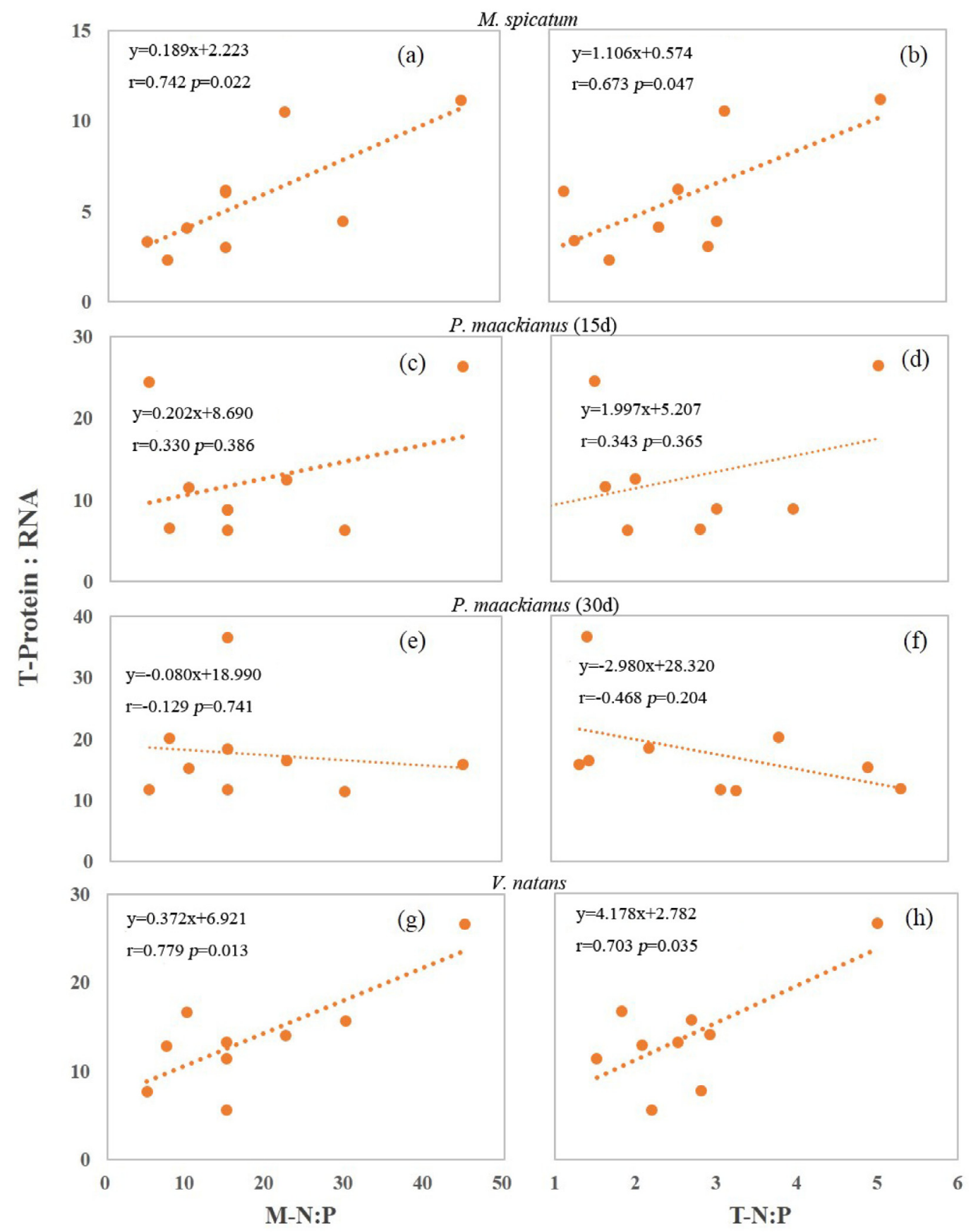

Fig. 7. Relationships of tissue Protein:RNA ratio with N:P ratio in culture medium and tissue at single species level.

M. spicatum and V. natans (Figure 7). And Protein:RNA ratios in $M$. spicatum and $V$. natans significantly correlated with $\mathrm{N}: \mathrm{P}$ in media and tissues, respectively. For P. maackianus (30d), Protein:RNA negatively correlated with N:P in media and tissues.

\subsection{Stoichiometric homeostasis}

Stoichiometric homeostasis coefficient $\left(H_{\mathrm{N}: \mathrm{P}}\right)$ of four submerged macrophytes are all below 5.0 (Figure 8). Stoichiometric homeostasis coefficient $\left(H_{\mathrm{N}: \mathrm{P}}\right)$ of 15 -day cultured
P. maackianus had no significant difference with that of 30day cultured $P$. maackianus. Stoichiometric homeostasis of $V$. natans was stronger than those of $P$. maackianus, M. spicatum and $C$. demersum.

\section{Discussion}

Our results showed positive associations of tissue C:N and $\mathrm{C}: \mathrm{P}$ ratios with growth rates for submerged macrophytes beside single species $V$. natans (Figures 1-6), which were contrary to many successful studies of GRH tests for plants 


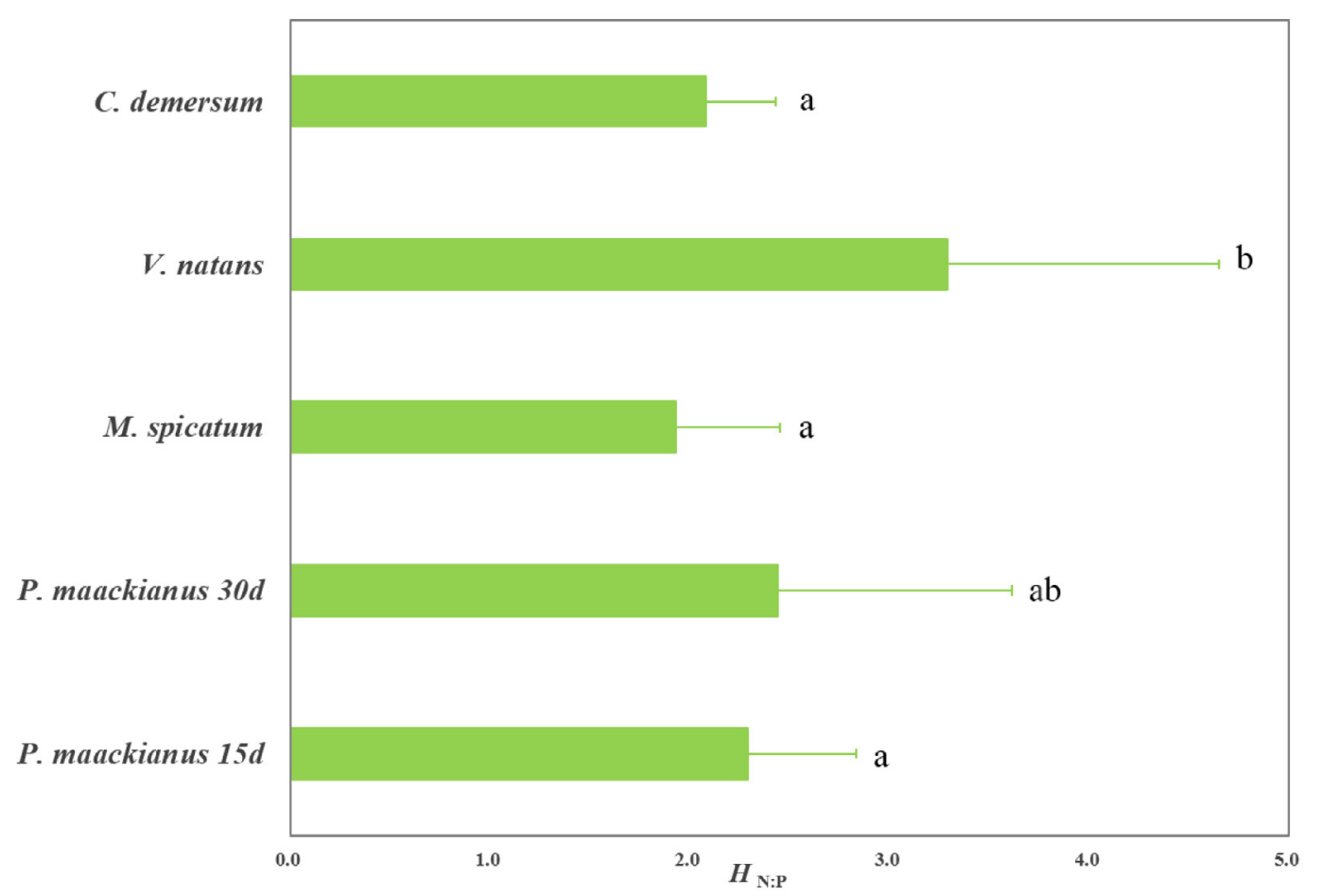

Fig. 8. Stoichiometric homeostasis coefficients $\left(H_{\mathrm{N}: \mathrm{P}}\right)$ for submerged macrophytes. Different letters indicate means statistically different.

(Ågren, 2004, 2008; Niklas, 2006; Peng et al., 2011; Poorter and Bergkotte, 1992). However, the positive associations were in line with the study for grassland vascular plants under excess supply of $\mathrm{N}$ and $\mathrm{P}$ (Yu et al., 2012). Significantly, plants in the two studies are all treated by excess supply of nutrients.

Most studies have shown a negative association between $\mathrm{N}: \mathrm{P}$ ratio and growth rate, not only among plant species but also within populations or cultivars of a given species (Cernusak et al., 2010; Elser et al., 2010; Güsewell, 2004). At the single species level, we only found the negative relationship in P. maackianus (30d), V. natans and C. demersum. We also did not find the negative relationship at multi-species level (Figure 6c). A decrease in $\mathrm{N}: \mathrm{P}$ with increasing growth rate should not necessarily be expected, because plants have other survival strategies besides growth (e.g. storage and defense) that require investment in $N$ and $P$ (Matzek and Vitousek, 2009). Excess uptake will confound the physiological need for elements at different relative growth rates with the capacity of excess uptake under N-rich and P-rich conditions (Matzek and Vitousek, 2009; Yu et al., 2012).

It is also reported that for vascular plants, growth rate is positively correlated with tissue $\mathrm{N}: \mathrm{P}$ ratio when growth rate is low, while negatively correlated with tissue N:P ratio when growth rate is high (Elser et al., 2010; Yu et al., 2012). In the study, four tested submerged macrophytes were threatened by eutrophication. As a result, positive correlation between growth rate and $\mathrm{N}: \mathrm{P}$ ratio should be found in the study. But our results were partly contrary to the report, which may be related to low growth rate and high nutrient concentration. For example, the average growth rate of $P$. maackianus (15d) was higher than that of P. maackianus (30d) (Figure S.1), which also indicated eutrophication can hamper growth of submerged macrophytes (Moss et al., 2012; Yu et al., 2015). In addition, P. maackianus (15d) and P. maackianus (30d) had opposite relationships between tissue N:P ratio and growth rate (Figures 1 and 2). Therefore, N:P ratio may be a good indicator of successful GRH tests for plants only under nutrient limitation condition.

We found negative correlations between protein:RNA ratios and growth rates in submerged macrophytes under eutrophication stress at the single species level and multi-species level, indicating GRH is applicable to submerged macrophytes threatened by eutrophication stress. GRH tests usually focus on the relationships among growth rate, P content, RNA content (Flynn et al., 2010; Peng et al., 2011; Reef et al., 2010; Yu et al., 2012), little is known about the relationship between growth rate and protein:RNA ratio (Matzek and Vitousek, 2009). GRH implies that the rate of protein synthesis per RNA is constant in different organisms and conditions (Elser et al., 2003; Giordano et al., 2015; Sterner and Elser, 2002). In addition, most previous studies on GRH tests have been done under N-limitaiton or/and P-limitation (Flynn et al., 2010; Lukas et al., 2011; Matzek and Vitousek, 2009; Peng et al., 2011; Yu et al., 2012), however, vascular plants especially aquatic vascular plants survived in eutrophication stress are very lacking for GRH tests.

Protein:RNA ratios positively correlated with N:P ratios in culture media and tissues in submerged macrophytes except in P. maackianus (30d) (Figure 7), showing effects of varying $\mathrm{N}: \mathrm{P}$ ratios in culture media on protein:RNA ratios are basically in concert with tissue N:P ratios under short-time eutrophication stress. The results are associated with survival strategies of plants and eutrophication stress. For example, under 
high-resource conditions, where rapid growth is a better competitive strategy than efficiency, a higher investment in ribosomes per unit protein maximizes the speed of protein synthesis (Matzek and Vitousek, 2009). Previous studies have applied the slope of body P and RNA-P to estimate the P allocation. If the slope is less than 1 , the $\mathrm{P}$ is mainly used for the synthesis of RNA; If the slope is more than 1, the P is mainly used for the synthesis of organic compounds, such as nucleoptides cursors (Elser et al., 2003; Matzek and Vitousek, 2009; Weider et al., 2004). In our study, we applied the slope of tissue $\mathrm{N}: \mathrm{P}$ and protein:RNA to estimate the $\mathrm{N}$ and $\mathrm{P}$ allocation in submerged macrophytes. Under eutrophication stress, slopes of submerged macrophytes beside $P$. maackianus (30d) were all more than 1 , indicating a great amount of $\mathrm{N}$ and $\mathrm{P}$ allocates to synthesis of other organic compounds, rather than protein and RNA.

Stoichiometric homeostasis coefficients $\left(H_{\mathrm{N}: \mathrm{P}}\right)$ for submerged macrophytes in the study were less than animals but more than algae and fungi, which is in agreement with many studies for vascular plants (Sistla and Schimel, 2012; Sterner and Elser, 2002; Xing et al., 2015; Yu et al., 2011). Most of previous studies on stoichiometric homeostasis have made comparisons between autotrophs and heterotrophs (Persson et al., 2010), or among heterotrophs (Karimi and Folt, 2006; Villar-Argaiz et al., 2002), whereas comparisons across plant species are relatively lacking. Yu et al. (2011) and Xing et al. (2015) made comparisons across vascular plants species in the Inner Mongolia grassland and across submerged macrophytes species in Yunnan plateau lakes, respectively. Yu et al. (2010) reported that species with strong homeostasis are dominant and stable in the community, while ecosystems dominated by homeostatic taxa are productive and stable. In the study, stoichiometric homeostasis of $V$. natans was stronger than those of $P$. maackianus, $M$. spicatum and $C$. demersum, indicating $V$. natans is relatively dominant and stable in the community of aquatic plants under eutrophication stress. The difference of stoichiometric homeostasis may be caused by species traits, such as growth and reproduction.

In conclusion, our results showed that

1. GRH can apply to submerged macrophytes under eutrophication stress, and the protein:RNA is a better indicator of GRH test for plants than N:P.

2. Submerged macrophytes species, P. maackianus, M. spicatum $C$. demersum and $V$. natans all have weak stoichiometric homeostasis.

Acknowledgements. The study was supported by National Natural Science Foundation of China (31370479) and the National S \& T Major Project (2012ZX07103003).

\section{References}

Ågren G.I., 2004. The C:N:P stoichiometry of autotrophs - theory and observations. Ecol. Lett., 7, 185-191.

Ågren G.I., 2008. Stoichiometry and nutrition of plant growth in natural communities. Annu. Rev. Ecol. Evol. Syst., 39, 153-170.

Ågren G.I. and Weih M., 2012. Plant stoichiometry at different scales: element concentration patterns reflect environment more than genotype. New Phytol., 194, 944-952.
Berdalet E., Latasa M. and Estrada M., 1994. Effects of nitrogen and phosphorus starvation on nucleic acid and protein content of Heterocapsa sp. J. Plankton Res., 16, 303-316.

Bradford M.M., 1976. A rapid and sensitive method for the quantitation of microgram quantities of protein utilizing the principle of protein-dye binding. Anal. Biochem. 72, 248-254.

Bremner J.M., 1996. Nitrogen-total. In: Sparks D.L. et al. (eds.), Methods of Soil Analysis Part 3: Chemical Methods. Soil Science Society of America and American Society of Agronomy, Madison, 1085-1123.

Cernusak L.A., Winter K. and Turner B.L., 2010. Leaf nitrogen to phosphorus ratios of tropical trees: experimental assessment of physiological and environmental controls. New Phytol., 185, 770-779.

Elser J.J., Acharya K., Kyle M., Cotner J., Makino W., Markow T., Watts T., Hobbie S., Fagan W., Schade J., Hood J. and Sterner R.W., 2003. Growth rate-stoichiometry couplings in diverse biota. Ecol. Lett., 6, 936-943.

Elser J.J., Fagan W.F., Kerkhoff A.J., Swenson N.G. and Enquist B.J., 2010. Biological stoichiometry of plant production: metabolism, scaling and ecological response to global change. New Phytol., 186, 593-608.

Flynn K.J., Raven J.A., Rees T.A.V., Finkel Z., Quigg A. and Beardall J., 2010. Is the growth rate hypothesis applicable to microalgae? J. Phycol., 46, 1-12.

Frost P.C., Evans-White M.A., Finkel Z.V., Jensen T.C. and Matzek V., 2005. Are you what you eat? Physiological constraints on organismal stoichiometry in an elementally imbalanced world. Oikos 109, 18-28.

Giordano M., Palmucci M. and Raven J.A., 2015. Growth rate hypothesis and efficiency of protein synthesis under different sulphate concentrations in two green algae. Plant Cell Environ., 38, 2313-2317.

Güsewell S., 2004. N: P ratios in terrestrial plants: variation and functional significance. New Phytol., 164, 243-266.

Hessen D.O., Ågren G.I., Anderson T.R., Elser J.J. and de Ruiter P.C., 2004. Carbon sequestration in ecosystems: the role of stoichiometry. Ecology 85, 1179-1192.

Hessen D.O., Jensen T.C., Kyle M. and Elser J.J., 2007. RNA responses to N- and P-limitation: reciprocal regulation of stoichiometry and growth rate in Brachionus. Funct. Ecol., 21, 956-962.

Karimi R. and Folt C.L., 2006. Beyond macronutrients: element variability and multielement stoichiometry in freshwater invertebrates. Ecol. Lett., 9, 1273-1283.

Karpinets T., Greenwood D., Sams C. and Ammons J., 2006. RNA:protein ratio of the unicellular organism as a characteristic of phosphorous and nitrogen stoichiometry and of the cellular requirement of ribosomes for protein synthesis. BMC Biol., 4, 30.

Klausmeier C.A., Litchman E., Daufresne T. and Levin S.A., 2004. Optimal nitrogen-to-phosphorus stoichiometry of phytoplankton. Nature 429, 171-174.

Kuo S., 1996. Phosphorus. In: Sparks D.L. et al., (eds.), Methods of Soil Analysis Part 3: Chemical Methods. Soil Science Society of America and American Society of Agronomy, Madison, 869-920.

Lukas M., Sperfeld E. and Wacker A., 2011. Growth Rate Hypothesis does not apply across colimiting conditions: cholesterol limitation affects phosphorus homoeostasis of an aquatic herbivore. Funct. Ecol., 25, 1206-1214.

Makino W., Cotner J., Sterner R. and Elser J., 2003. Are bacteria more like plants or animals? Growth rate and resource dependence of bacterial C:N:P stoichiometry. Funct. Ecol., 17, 121-130. 
Matzek V. and Vitousek P.M., 2009. N:P stoichiometry and protein:RNA ratios in vascular plants: an evaluation of the growthrate hypothesis. Ecol. Lett., 12, 765-771.

Meng W., 2009. System engineering for water pollution control at the watershed level in China. Front. Environ. Sci. Engin. China, 3, 443-452.

Meunier C.L., Malzahn A.M. and Boersma M., 2014. A new approach to homeostatic regulation: towards a unified view of physiological and ecological concepts. PLOS ONE 9, e107737.

Moss B., Jeppesen E., Søndergaard M., Lauridsen T. and Liu Z., 2012. Nitrogen, macrophytes, shallow lakes and nutrient limitation: resolution of a current controversy? Hydrobiologia, 710, 3-21.

Niklas K.J., 2006. Plant allometry, leaf nitrogen and phosphorus stoichiometry, and interspecific trends in annual growth rates. Ann. Bot., 97, 155-163.

Peng Y., Niklas K.J. and Sun S., 2011. The relationship between relative growth rate and whole-plant $\mathrm{C}: \mathrm{N}: \mathrm{P}$ stoichiometry in plant seedlings grown under nutrient-enriched conditions. $J$. Plant Ecol., 4, 147-156.

Persson J., Fink P., Goto A., Hood J.M., Jonas J. and Kato S., 2010. To be or not to be what you eat: regulation of stoichiometric homeostasis among autotrophs and heterotrophs. Oikos, 119, $741-751$.

Poorter H. and Bergkotte M., 1992. Chemical composition of 24 wild species differing in relative growth rate. Plant Cell Environ. 15, 221-229.

Reef R., Ball M.C., Feller I.C. and Lovelock C.E., 2010. Relationships among RNA:DNA ratio, growth and elemental stoichiometry in mangrove trees. Funct. Ecol., 24, 1064-1072.

Sistla S.A. and Schimel J.P., 2012. Stoichiometric flexibility as a regulator of carbon and nutrient cycling in terrestrial ecosystems under change. New Phytol., 196, 68-78.
Sterner R.W. and Elser J.J., 2002. Ecological stoichiometry: the biology of elements from molecules to the biosphere. Princeton University Press, Princeton, New Jersey.

Villar-Argaiz M., Medina-Sánchez J.M. and Carrillo P., 2002. Linking life history strategies and ontogeny in crustacean zooplankton: implications for homeostasis. Ecology 83, 1899-1914.

Vrede T., Persson J. and Aronsen G., 2002. The influence of food quality (P:C ratio) on RNA: DNA ratio and somatic growth rate of Daphnia. Limnol. Oceanogr., 47, 487-494.

Wang Y., Gao G., Qin B. and Wang X. 2012. Ecophysiological and anatomical responses of Vallisneria natans to nitrogen and phosphorus enrichment. Knowl. Manag. Aquat. Ecosyst., 405, 05.

Weider L.J., Glenn K.L., Kyle M. and Elser J.J., 2004. Associations among ribosomal (r) DNA intergenic spacer length, growth rate, and C:N:P stoichiometry in the genus Daphnia. Limnol. Oceanogr., 49, 1417-1423.

Xing W., Wu H., Shi Q., Hao B., Liu H., Wang Z. and Liu G., 2015. Multielement stoichiometry of submerged macrophytes across Yunnan plateau lakes (China). Sci. Rep., 5, 10186.

Yu Q., Chen Q., Elser J.J., He N., Wu H., Zhang G., Wu J., Bai Y. and Han X., 2010. Linking stoichiometric homoeostasis with ecosystem structure, functioning and stability. Ecol. Lett., 13, 1390-1399.

Yu Q., Elser J.J., He N., Wu H., Chen Q., Zhang G. and Han X., 2011. Stoichiometric homeostasis of vascular plants in the Inner Mongolia grassland. Oecologia, 166, 1-10.

Yu Q., Wu H., He N., Lü X., Wang Z., Elser J.J., Wu J. and Han X., 2012. Testing the growth rate hypothesis in vascular plants with above- and below-ground biomass. PLOS ONE, 7, e32162.

Yu Q., Wang H.Z., Li Y., Shao J.C., Liang X.M., Jeppesen E. and Wang H.J., 2015. Effects of high nitrogen concentrations on the growth of submersed macrophytes at moderate phosphorus concentrations. Water Res., 83, 385-395.

Cite this article as: W. Xing, Q. Shi, H. Liu and G. Liu, 2016. Growth rate, protein:RNA ratio and stoichiometric homeostasis of submerged macrophytes under eutrophication stress. Knowl. Manag. Aquat. Ecosyst., 417, 25. 


\section{Supporting information}

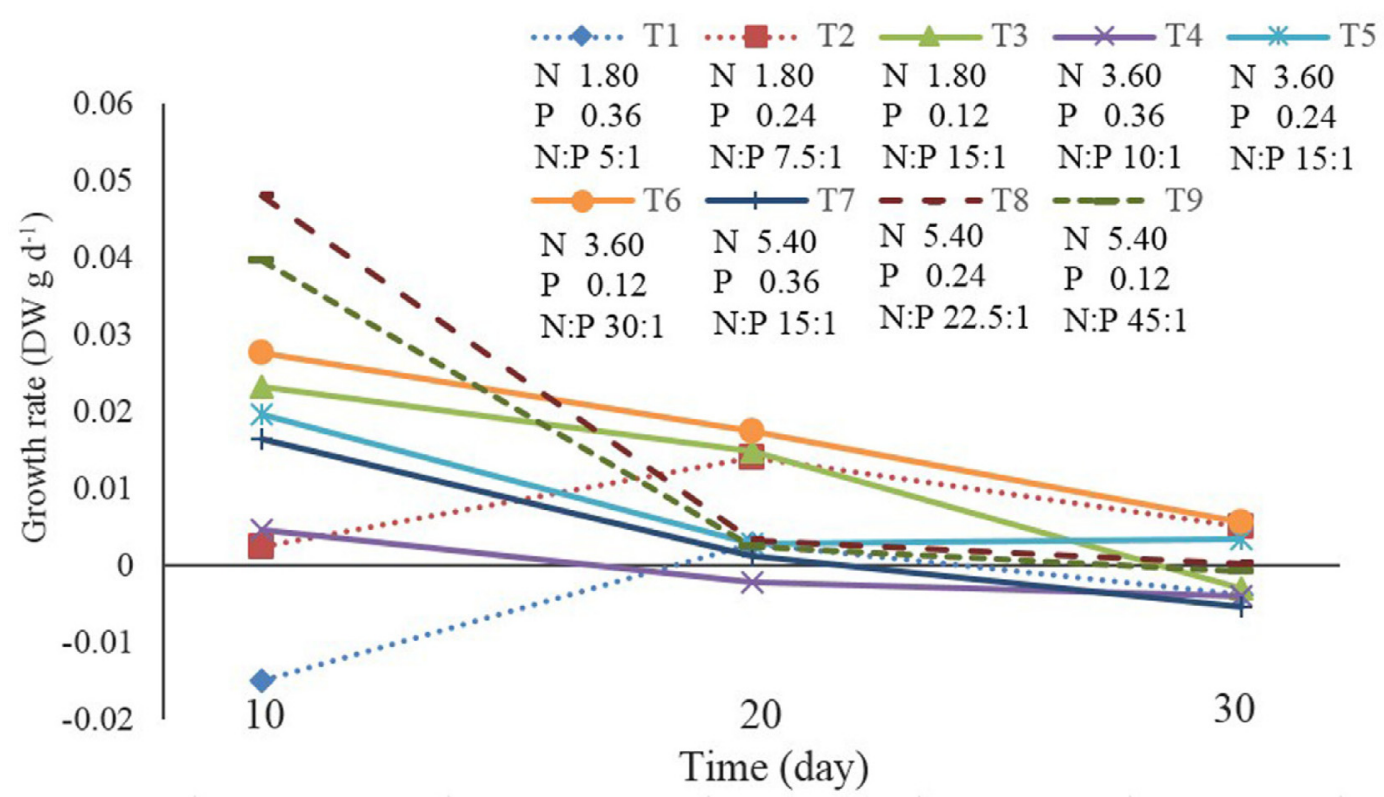

Fig. S.1. Changes in growth rate of P. maackianus under different N/P concentrations and ratios. 